\title{
Effect of pequi shell ethanolic extract on glutathione reductase activity in rats exposed to doxorubicin cardiotoxicity
}

\author{
Efeito do extrato etanólico da casca do pequi sobre a enzima \\ glutationa redutase em ratos submetidos à cardiotoxicidade \\ por doxorrubicina
}

\author{
Léa Resende Moura', Ângela Alves Viegas², Loanny Maria de Almeida ${ }^{3}$, Raquel Emanuelle de Jesus Neves³ , \\ Claudinei Sousa Lima* ${ }^{4 *}$ Veridiana Maria Brianezi Dignani de Moura ${ }^{5}$ \\ 'Veterinary, Dr. Escola de Medicina, Centro Universitário UniEvangélica, Anápolis, GO, Brasil \\ ²Biomedical, MSc. Escola de Medicina, Centro Universitário Unievangélica, Anápolis, GO, Brasil \\ ${ }^{3}$ Graduate students in Biological Science. Faculdade Metropolitana de Anápolis, Anápolis, GO, Brasil \\ 4Pharmaceutical, Dr. Unidade Universitária de Ciências Exatas e Tecnológicas, Universidade Estadual de Goiás, Anápolis, GO, Brasil \\ ${ }^{5}$ Veterinary, Dr. Escola de Veterinária e Zootecnia, Universidade Federal de Goiás, Federal University of Goiás, Goiânia, GO, Brasil
}

\begin{abstract}
Doxorubicin (DOX), a chemotherapeutic agent from the anthracycline family, is used in the treatment of various neoplasms. However, it has cardiotoxic side effects. The objective of this study was to evaluate the effect of pequi shell ethanolic extract (PSEE) on the activity of the antioxidant enzyme glutathione reductase (GSH-Rd) in the myocardium of rats exposed to DOX cardiotoxicity, administered intraperitoneally at a single dose of $16 \mathrm{mg} / \mathrm{kg}$. Wistar rats were divided into six groups $(\mathrm{n}=5)$. To the rats of the sham group (SG) was administered with $1 \mathrm{~mL}$ of physiological saline solution. The control group (CG) was treated with 16 mg/kg DOX; G1 with 16 mg/kg DOX and 300 mg/kg PSEE for 17 days; G2 with 16 mg/kg DOX and $600 \mathrm{mg} / \mathrm{kg}$ PSEE for 17 days; G3 with $16 \mathrm{mg} / \mathrm{kg}$ DOX and 300 mg/kg PSEE for 10 days; and G4 with $16 \mathrm{mg} / \mathrm{kg}$ DOX and $600 \mathrm{mg} / \mathrm{kg}$ PSEE for 10 days. The quantity of absorbed light was measured by spectopotometry to quantify the enzymatic activity. The daily administration of PSEE at $300 \mathrm{mg} / \mathrm{kg}$ for 17 days significantly increased the enzymatic activity of GSH-Rd (19.58 $\pm 5.92 \mu \mathrm{mol} \cdot \mathrm{min}^{-1} \cdot \mathrm{g}^{-1}$ protein) more than those of the control $\left(2.48 \pm 4.52 \mu \mathrm{mol} \cdot \mathrm{min}^{-1} \cdot \mathrm{g}^{-1}\right.$ protein $)$ and sham groups $\left(3.28 \pm 4.57 \mu \mathrm{mol} \cdot \mathrm{min}^{-1} \cdot \mathrm{g}^{-1}\right.$ protein). It was concluded that PSEE daily administration at $300 \mathrm{mg} / \mathrm{kg}$ for 17 days increased the activity of the enzyme GSH-Rd.
\end{abstract}

Keywords: oxidative stress, GSH-Rd, Caryocar brasiliense.

\section{Resumo}

A doxorrubicina (DOX) é um quimioterápico da família das antraciclinas, utilizado no tratamento de diversas neoplasias. No entanto, possui efeito colateral cardiotóxico. Este estudo teve por objetivo avaliar a ação do extrato etanólico da casca do pequi (EECP) sobre a atividade da enzima antioxidante glutationa redutase (GSH-Rd) no miocárdio de ratos submetidos à cardiotoxicidade por DOX, administrada na dose única de $16 \mathrm{mg} / \mathrm{kg}$, por via intraperitoneal. Foram utilizados 30 ratos da raça Wistar, distribuídos em seis grupos ( $\mathrm{n}=5$ ). Nos ratos do grupo sham (GS) foi aplicado $1 \mathrm{~mL}$ de solução fisiológica. Os animais do controle (GC) receberam $16 \mathrm{mg} / \mathrm{kg}$ de DOX; do G116 mg/kg de DOX e $300 \mathrm{mg} / \mathrm{kg}$ de EECP durante 17 dias; do G2 16 mg/kg de DOX e 600 mg/kg de EECP durante 17 dias; do $G 316$ mg/kg de DOX e 300 mg/kg de EECP durante 10 dias; e do G4 16 mg/kg de DOX e 600 mg/kg de EECP durante 10 dias. A quantidade de luz absorvida foi medida por espectofotometria para quantificar a atividade enzimática. Na dose de $300 \mathrm{mg} / \mathrm{kg}$ durante 17 dias o EECP aumentou significativamente a atividade enzimática da GSH-Rd $\left(19,58 \pm 5,92 \mu \mathrm{mol} \cdot \mathrm{min}^{-1} \cdot \mathrm{g}^{-1}\right.$ de proteína $)$ em comparação aos grupos controle $\left(2,48 \pm 4,52 \mu \mathrm{mol} \cdot \mathrm{min}^{-1} \cdot \mathrm{g}^{-1}\right.$ de proteína) e sham (3,28 $\pm 4,57 \mu \mathrm{mol} \cdot \mathrm{min}^{-1} \cdot \mathrm{g}^{-1}$ de proteína). Conclui-se que o EECP na dose de $300 \mathrm{mg} / \mathrm{kg}$ durante 17 dias aumenta a atividade da enzima GSH-Rd.

Palavras-chave: estresse oxidativo, GSH-Rd, Caryocar brasilense.
How to cite: Moura, L. R., Viegas, A. A., Almeida, L. M., Neves, R. E. J., Lima, C. S., \& Moura, V. M. B. D. (2018). Effect of pequi shell ethanolic extract on glutathionereductase activity in rats exposed to doxorubicin cardiotoxicity. Brazilian Journal of Veterinary Medicine,20, e89018. doi: 10.29374/2527-2179.bjvm89019

Financial support: Conselho Nacional de Desenvolvimento Científico e Tecnológico - CNPq.

Conflict of interests: No conflict of interests declared concerning the publication of this article.

Received: March 03, 2018

Accepted: June 06, 2018

The study was carried out at Universidade Estadual de Goiás - UEG, Anápolis, GO, Brazil.

\section{${ }^{*}$ Correspondence}

Claudinei Sousa Lima

Unidade Universitária de Ciências Exatas e Tecnológicas, Universidade Estadual de Goiás - UEG

BR 153, Campus Henrique Santilo, Zona Rural CEP 75132-903 - Anápolis (GO), Brasil

E-mail: claudineimorfo@gmail.com
Copyright Moura et al. This is an Open Access article distributed under the terms of the Creative Commons Attribution Non-Commercial License which permits unrestricted non-commercial use, distribution, and reproduction in any medium provided the original work is properly cited. 


\section{Introduction}

Doxorubicin (DOX), a drug from the anthracycline group, is commonly used in the treatment of various neoplasms. However, it has cardiotoxic side effects due to its relationship with cellular biochemical processes. The cardiotoxicity of DOX is exerted through various mechanisms, mainly through the promotion of free-radical production (Moura et al., 2015).

The major antioxidant complexes in the body are classified as enzymatic and non-enzymatic antioxidants. Antioxidant enzymes are responsible for maintaining low concentrations of superoxide and hydrogen peroxide. These enzymes exert negative effects on reactive oxygen species and, potentially, also on the oxidative lesions caused by these radicals (Barreiros et al., 2006). The enzymatic antioxidants consist mainly of superoxide dismutase, catalase, glutathione peroxidase, and glutathione reductase (GSH-Rd), all of which catalyze oxidation reactions and prevent the formation of intermediate radicals (Pereira, 2011). These enzymes are notable for serving as highly specific tissue biomarkers of their substrates and for neutralizing free radicals before they participate in chain reactions (Prada et al., 2004).

Non-enzymatic antioxidants, supplied by the diet, are naturally occurring substances, including minerals, vitamins, carotenoids, tannins, and phenolic compounds (Shami \& Moreira, 2004). These substances are capable of protecting cells exposed to DOX-induced cardiotoxicity, potentially by neutralizing free radicals. The use of non-enzymatic antioxidants stimulates the gene expression of catalase, superoxide dismutase, glutathione peroxidase, and GSH-Rd, increasing cellular antioxidant capacity (Cerqueira et al., 2007).

Pequi (Caryocar brasilense) is a fruit frequently found in the Cerrado of the Center-West Region of Brazil, and has therapeutic use due to its antioxidant properties (Miranda-Vilela et al., 2009). This species is found mainly in the Cerrado (savannah), Cerradão (dry forest), and Mata Calcária (limestone forest). According to Roesler et al. (2007), pequi is one of the fruits in the Cerrado with the highest concentration of phenolic compounds. This compound, which can be efficiently produced through the ethanolic extraction of pequi shell, neutralizes free radicals by donating hydrogen molecules.

Studies have indicated that natural antioxidant substances exert their protective effects on cardiac cells exposed to DOX-induced injury by neutralizing and reducing the free radicals levels (Xin et al., 2011). On the basis of several studies that evaluated the biological activity and therapeutic use of pequi, this study aimed to evaluate the effect of pequi shell ethanolic extract (PSEE) on the activity of the antioxidant enzyme GSH-Rd in the myocardium of rats exposed to DOX.

\section{Materials and methods}

This study was authorized by the Research Ethics Committee of the State University of Goiás (REC/FUG 028/12) and conducted in accordance with the ethical precepts in animal experiments recommended by the Brazilian Society of Laboratory Animal Science.

To obtain PSEE, pequi fruit peels were extracted according to a technique described by Moura et al. (2017). Following extraction, the PSEE was stored at $-20^{\circ} \mathrm{C}$ until use. Thirty 3-month old male Wistar rats (Rattus norvegicus albinus), which weighed 224-483 g, were divided into six groups: Sham Group (SG), Control Group (CG), Group 1 (G1), Group 2 (G2), Group 3 (G3), and Group $4(\mathrm{G} 4)(\mathrm{n}=5)$. The experiment lasted 17 days, with the DOX and the physiological saline solution being administered on the $14^{\text {th }}$ day, adapted from a method used by Xin et al. (2011). The doses of PSEE used in this study were previously described by Miguel et al. (2012).

In the CG, G1, G2, G3, and G4 groups, cardiotoxicity was induced by a single intraperitoneal injection of $16 \mathrm{mg} / \mathrm{kg}$ DOX (Adriblastina ${ }^{\circledR}$, Pfizer, Milan, Italy), in accordance with a method described by Karimi et al. (2005). On the other hand, the SG rats were intraperitoneally injected with $1 \mathrm{~mL}$ of physiological saline solution. The peritoneal treatments were administered using catheter number 22 after antisepsis with iodopovidone (Riodeine ${ }^{\circledR}$, Rioquímica, São José do Rio Preto, São Paulo, Brazil). G1 and G2 rats were orally administered with 300 and 600 mg/kg of PSEE, respectively, for 17 days. During the first seven days, the SG, CG, G3, and G4 groups orally received $1 \mathrm{~mL}$ of water. Starting from day 8, the G3 and G4 rats orally received 300 and $600 \mathrm{mg} / \mathrm{kg}$ of PSEE, respectively, every day until day 17. Similarly, animals from groups SG and CG were administered 
with $1 \mathrm{~mL}$ of water daily until the last day of the experiment. Thus, these last four groups were subjected to 10 days of treatment.

At the end of the experiment, the rats were anesthetized with isoflurane in 100\% oxygen (Isoforini ${ }^{\circledR}$, Cristália, Itapira, São Paulo, Brazil) in a closed inhalation chamber and subsequently euthanized by anesthetic overdose. The anesthesia was administered by using a vaporizer (Oxigel, Vaporizador Universal, São Paulo/SP, Brazil) with a gas flow of $1 \mathrm{~L} / \mathrm{min}$ through a face mask designed for rats. The animals' hearts were harvested and stored in liquid nitrogen at $-80^{\circ} \mathrm{C}$.

For the evaluation of GSH-Rd enzymatic activity, fragments of the cardiac ventricles were suspended in $0.1 \mathrm{M}$ phosphate buffer $\left(\mathrm{SIGMA}^{\circledR}\right)$ ( $\mathrm{pH}$ 7.0) equal to four times the absolute value of the sample. Next, the samples were homogenized in a Potter-Elvehjim homogenizer. The homogenate was centrifuged at 1,010 $\mathrm{x} g$ for $20 \mathrm{~min}$ at $4{ }^{\circ} \mathrm{C}$ and the supernatant was used to gauge the enzymatic activities.

The activity of GSH-Rd was examined using a method described by Carlberg \& Mannervik (1985). The enzyme was suspended in a reaction medium containing $25 \mathrm{~mL}$ of $0.1 \mathrm{M}$ phosphate buffer (pH 7.0), 4.3 mg of NADPH (SIGMA $\left.{ }^{\circledR}\right), 16.35$ mg of oxidized glutathione (SIGMA ${ }^{\circledR}$ ), 5 mL of 5 mMEDTA (VETEC ${ }^{\circledast}$ ) (pH 7.0), and 7.5 mL of distilled water. Next, the absorbance was measured at $340 \mathrm{~nm}$ using a spectrophotometer at a temperature of $23^{\circ} \mathrm{C}$. The activity of the enzyme was expressed as $\mu \mathrm{mol} . \mathrm{min}^{-1}$. $\mathrm{g}^{-1}$ of protein.

The experiment was conducted in a completely randomized design with six experimental groups and five replicates in each group, thus involving 30 rats in total. A linear model was created using the statistical software R version 3.0.0 (R CORE development team), with a significance level of $5 \%(\alpha=5 \%)$. The data are presented as the mean and standard deviation.

\section{Results}

The activity of GSH-Rd enzyme in the rat cardiac tissue was measured and the GSH-Rd activities ( $\mu$ mol.min ${ }^{-1} \cdot \mathrm{g}^{-1}$ of protein) of the SG, CG, G1, G2, G3, and G4 groups were $3.28 \pm 4.57,2.48 \pm 4.52$, $19.58 \pm 5.92,8.85 \pm 10.53,6.44 \pm 7.017$, and $7.66 \pm 9.057$, respectively.

According to the linear model, the mean GSH-Rd activity of the group treated with $300 \mathrm{mg} / \mathrm{kg}$ of PSEE for 17 days (G1 $=19.58 \pm 5.92 \mu \mathrm{mol} \cdot \mathrm{min}^{-1} \cdot \mathrm{g}^{-1}$ of protein) was significantly higher than that of the control (CG $=2.48 \pm 4.52 \mu \mathrm{mol} \cdot \mathrm{min}^{-1}{ }^{-1}{ }^{-1}$ of protein) and sham groups (SG $=3.28 \pm 4.57 \mu \mathrm{mol} \cdot \mathrm{min}^{-1} \cdot \mathrm{g}^{-1}$ of protein) (Table 1 ). The GSH-Rd activity data of each group are shown in Figure 1.

Table 1. Results of the linear model comparing the effects of each treatment with those in the control and sham groups.

\begin{tabular}{ccccc}
\hline Groups x CG & B & Standard Error & T & P \\
\hline CG & 0.0051 & 0.0009023 & 5.652 & $<0.001$ \\
G1 & 0.00346 & 0.001276 & 2.712 & 0.013 \\
G2 & 0.00042 & 0.001276 & 0.329 & 0.746 \\
G3 & -0.0017 & 0.001276 & 1.332 & 0.198 \\
G4 & 0.00248 & 0.001276 & 1.944 & 0.066 \\
\hline Groups x SG & B & Standard Error & T & $\mathbf{P}$ \\
\hline SG & 0.00456 & 0.001022 & 4.462 & $<0.001$ \\
G1 & -0.00292 & 0.001445 & -2.021 & 0.057 \\
G2 & 0.00012 & 0.001445 & 0.083 & 0.935 \\
G3 & -0.00116 & 0.001445 & -0.803 & 0.432 \\
G4 & -0.00194 & 0.001445 & -1.342 & 0.194 \\
\hline
\end{tabular}

CG = control group; SG = sham group; B = Coefficient of slope of the line; Student 's t test; P = P Value; G1 = Group 1; G2 = Group 2; G3 = Group 3; G4 = Group 4. 

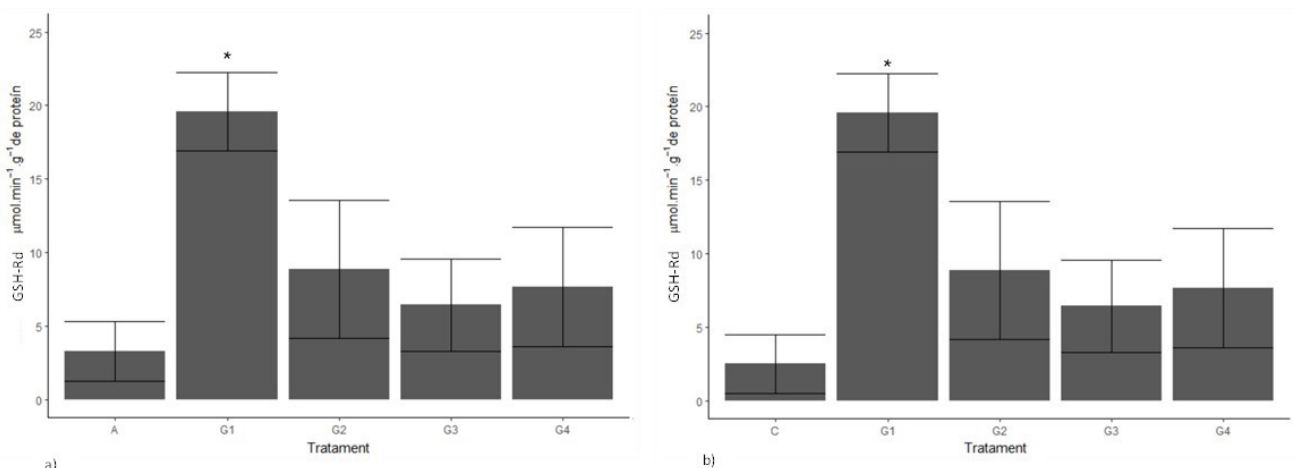

Figure 1. Comparison of GSH-Rd enzyme activities in the myocardium of rats exposed to DOX. a) Comparison between the sham (A) and PSEE-treated groups: G1 (Group 1), G2 (Group 2), G3 (Group 3) and G4 (Group 4), in which G1 presented a significantly higher GSH-Rd activity $\left({ }^{*}=\mathrm{p}<0.05\right)$ than the sham group (A). b) Comparison between the control (C) and PSEE-treated groups, in which G1 presented a significantly higher GSH-Rd activity $\left({ }^{*}=\mathrm{p}<0.05\right)$ than the control group $(\mathrm{C})$; The bars and lines indicate the means and standard error, respectively.

\section{Discussion}

In the present study, the daily administration of PSEE at a dose of $300 \mathrm{mg} / \mathrm{kg}$ for 17 days significantly increased the activity of GSH-Rd enzyme in the hearts of DOX-treated rats, indicating an antioxidant effect of PSEE on the rat cardiac tissue and confirming that the effect occurred through a biochemical cascade mediated by GSH-Rd. Glutathione peroxidase reduces hydrogen peroxide to water by converting reduced glutathione (GSH) to oxidized glutathione (GSSG). The latter promotes oxidation owing to the disulfide bond present in its structure. On the other hand, GSH-Rd is responsible for the recovery of GSH, which maintains the redox cycle of glutathione and the balance between oxidant and antioxidant activities (Barbosa et al., 2010). Thus, after the exposure to the oxidizing agent, the oxidation of GSH to GSSG occurs. The GSH recovery process, catalyzed by the enzyme GSH-Rd, is an essential step in maintaining the integrity of the cellular protection system. Hence, the abundant presence of GSH-Rd in the cardiac tissue indicated a higher antioxidant activity in the hearts of PSEE-treated rats than in those of the untreated rats. These findings are consistent with those of other studies on natural antioxidant drugs, which described similar effects under the same mechanisms (Khan et al., 2005; Iqbal et al., 2008; Koti et al., 2009).

Reactive oxygen species are capable of modulating the activity of antioxidant enzymes by regulating the mRNA levels of the enzymes through the activation of signaling pathways. Reactive oxygen species interfere with the regulation of various cellular functions by acting as second messengers and activating specific transcription factors, such as AP-1 transcription factor and the nuclear factor kappa-light-chain-enhancer of activated B cells (NF-kappa B complex subunits) (Zhou et al., 2001).

In the present study, GSH-Rd activity was significantly higher in the rats receiving $300 \mathrm{mg} / \mathrm{kg}$ of PSEE daily for 17 days than in the control and sham groups, indicating that pequi is a promising fruit to produce a natural drug with oxidative stress-reducing activity. Furthermore, the increased levels of GSH-Rd enzyme in the cardiac tissue is an important indicator of the ability of cells to detoxify reactive oxygen species (Kumar et al., 2016).

The GSH-Rd activity in the heart of the control group, which received only DOX, was the lowest among the studied groups. This indicated that an imbalance between the oxidant and antioxidant enzymatic activity, as well as a subsequent oxidative injury in the rat heart, had occurred because of chemotherapy. This effect is confirmed by previous studies that reported the deleterious effect of the DOX through oxidative stress induction and excessive free-radical production (Karimi et al., 2005; Ferreira et al., 2007). Because of the absence of antioxidant (in the case PSEE) which should have aided in the neutralization of these radicals, the enzyme level in the CG group was even lower than those in the rats treated only with physiological saline solution.

PSEE at 300 and $600 \mathrm{mg} / \mathrm{kg}$, as reported by Miguel et al. (2012), exerts neuroprotective antioxidant activity. However, the authors emphasize the need for additional studies in the 
toxicological evaluation of the extract. In the present study, it was initially believed that daily PSEE administration at a dose of $600 \mathrm{mg} / \mathrm{kg}$ for 17 days (G2) would induce the highest enzymatic activity. However, it was PSEE at $300 \mathrm{mg} / \mathrm{kg}$ which induced a significant increase in GSH-Rd activity, indicating a great antioxidant potential of PSEE at this dose. This finding corroborated that described by Kang et al. (1996), in which the highest enzymatic activity were induced by pre-treatment with the antioxidant amifostine at the same dose. According to the authors, the pre-treatment with antioxidants induced a reduction in DOX cardiotoxicity because the study drug decreases free radicals generation. These effects may be attributed to antagonistic stereoisomers, such as flavonoid stereoisomers (Santos et al., 2007).

The present study did not evaluate the rat heart morphology. However, we used the same extract as well as a similar methodology to that described by Moura et al. (2017), who have proved the beneficial effects of PSEE on myocardial cells in the presence of DOX. Therefore, we considered that the results of the present study would reflect positively on deleterious effects of DOX on rat myocardium.

Additional studies should be conducted to determine the effect of pequi shell extract on the activity of other antioxidant enzymes, to isolate the active compounds of the extract, and to test the effects of the bioactive compounds in various animal species using various administration routes and dosages. It should be emphasized that in order to ensure the safety of the use of PSEE, it is essential to examine the potential toxic effect of the extract.

\section{Conclusion}

It was concluded that the daily oral administration of PSEE at a dose of $300 \mathrm{mg} / \mathrm{kg}$ for 17 days increased the enzymatic activity of GSH-Rd.

\section{Acknowledgements}

The authors are grateful to the National Council for Scientific and Technological Development (Conselho Nacional de Desenvolvimento Científico eTecnológico - CNPq) for funding this study.

\section{References}

Barbosa, K. B. F., Costa, N. M. B., Alfenas, R. C. G., Paula, S. O., Minim, V.P. R., \& Bressan, J. (2010). Estresse oxidativo: conceito, implicações e fatores modulatórios. Revista de Nutrição, 23(4), 629-643. http://dx.doi.org/10.1590/ S1415-52732010000400013.

Barreiros, A. L. B. S., David, J. M., \& David, J. P. (2006). Estresse oxidativo: relação entre geração de espécies reativas e defesa do organismo. Química Nova, 29(1), 113-123. http://dx.doi.org/10.1590/S0100-40422006000100021.

Carlberg, I., \& Mannervik, B. (1985). Glutathione reductase. Methods in Enzymology, 113, 484-490. http://dx.doi. org/10.1016/S0076-6879(85)13062-4. PMid:3003504.

Cerqueira, F. M., Medeiros, M. H. G., \& Augusto, O. (2007). Antioxidantes dietéticos: controvérsias e perspectivas. Química Nova, 30(2), 441-449. http://dx.doi.org/10.1590/s0100-40422007000200036.

Ferreira, A. L., Russell, R. M., Rocha, N., Placido Ladeira, M. S., Favero Salvadori, D. M., Oliveira Nascimento, M. C. M., Matsui, M., Carvalho, F. A., Tang, G., Matsubara, L. S., \& Matsubara, B. B. (2007). Effect of lycopene on doxorubicin-induced cardiotoxicity: an echocardiographic, histological and morphometrical assessment. Basic \& Clinical Pharmacology \& Toxicology, 101(1), 16-24. http://dx.doi.org/10.1111/j.1742-7843.2007.00070.x. PMid:17577311.

Iqbal, M., Dubey, K., Anwer, T., Ashish, A., \& Pillai, K. K. (2008). Protective effects of telmisartan against acute doxorubicin-induced cardiotoxicity in rats. Pharmacological Reports, 60(3), 382-390. PMid:18622063.

Kang, Y. J., Chen, Y., \& Epstein, P. N. (1996). Suppression of doxorubicin cardiotoxicity by overexpression of catalase in the heart of transgenic mice. The Journal of Biological Chemistry, 271(21), 12610-12616. http://dx.doi. org/10.1074/jbc.271.21.12610. PMid:8647872.

Karimi, G., Ramezani, M., \& Abdi, A. (2005). Protective effects of lycopene and tomato extract against doxorbicininduced cardiotoxicity. Phytotherapy Research,19(10), 912-914. http://dx.doi.org/10.1002/ptr.1746. PMid:16261525.

Khan, M., Shobha, J. C., Mohan, I. K., Naidu, M. U., Sundaram, C., Singh, S., Kuppusamy, P., \& Kutala, V. K. (2005). Protective effect of Spirulina against doxorubicin induced cardiotoxicity. Phytotherapy Research, 19(12), 1030-1037. http://dx.doi.org/10.1002/ptr.1783. PMid:16372368.

Koti, B. C., Vishwanathswamy, A. H., Wagawade, J., \& Thippeswamy, A. H. (2009). Cardioprotective effect of lipistat against doxorubicin induced myocardial toxicity in albino rats. Indian Journal of Experimental Biology, 47(1), 41-46. PMid:19317350. 
Kumar, V., Abbas, A., \& Aster, J. (2016). Robbins \& Cotran: bases patológicas das doenças (9a ed., pp. 48). Rio de Janeiro: Elsevier.

Miguel, M. P., Menezes, L. B., \& Araújo, E. G. (2012). Fisiopatologia do estresse oxidativo após isquemia e reperfusão cerebral e potencial neuroproteção do pequi (Caryocar brasiliense). Enc Biosfera, 8(15), 1960-1976.

Miranda-Vilela, A. L., Grisolia, C. K., Resck, I. S., \& Mendonça, M. A. (2009). Characterization of the major nutritional components of Caryocar brasiliense fruit pulp by NMR spectroscopy. Química Nova, 32(9), 2310-2313. http:// dx.doi.org/10.1590/S0100-40422009000900013.

Moura, L. R., Orpinelli, S. R. T., Sousa, J. H., Faleiro, M. B. R., Conceição, E. C., Sugita, D. M., Beletti, M. E., \& Moura, V. M. B. D. (2017). Ação do extrato etanólico da casca do pequi (Caryocar brasiliense) na cardiotoxicidade crônica induzida por doxorrubicina em ratos. Pesquisa Veterinária Brasileira, 37(7), 713-724. http://dx.doi. org/10.1590/s0100-736x2017000700011.

Moura, L. R., Viegas, Â. A., Nasciutti, P. R., Carvalho, R. O. A., \& Moura, V. M. B. D. (2015). Cardiotoxicidade induzida pela doxorrubicina: patogenia, diagnóstico e terapias antioxidantes. Enc Biosfera, 12, 711-736.

Pereira, F. E. L. (2011). Etiopatogênese geral das lesões. In G. Brasileiro Filho (Ed.), Bogliolo patologia (8a ed., pp. 49-50). Rio de Janeiro: Guanabara Koogan.

Prada, F. J. A., Macedo, D. V., Voltarelli, F. A., Oliveira, C. A. M., Gobatto, C. A., \& Mello, M. A. R. (2004). Condicionamento aeróbio e estresse oxidativo em ratos treinados por natação em intensidade equivalente ao limiar anaeróbio. Rev Bras Cien Mov., 12, 29-34.

Roesler, R., Malta, L. G., Carrasco, L. C., Holanda, R. B., Sousa, C. A. S., \& Pastore, G. M. (2007). Atividade antioxidante de frutas do cerrado. Food Science and Technology, 27(1), 53-60. http://dx.doi.org/10.1590/ S0101-20612007000100010.

Santos, A. R., Pinheiro, A. C., Sodero, A. C. R., Cunha, A. S., Padilha, M. C., Sousa, P. M., Fontes, S. P., Veloso, M. P., \& Fraga, C. A. M. (2007). Atropoisomerismo: o efeito da quiralidade axial em substâncias bioativas. Química Nova, 30(1), 125-135. http://dx.doi.org/10.1590/S0100-40422007000100024.

Shami, N. J. I. E., \& Moreira, E. A. M. (2004). Licopeno como agente antioxidante. Revista de Nutrição, 17(2), 227236. http://dx.doi.org/10.1590/S1415-52732004000200009.

Xin, Y. F., Wan, L. L., Peng, J. L., \& Guo, C. (2011). Alleviation of the acute doxorubicin-induced cardiotoxicity by Lycium barbarum polysaccherides through the suppression of oxidative stress. Food and Chemical Toxicology, 49(1), 259-264. http://dx.doi.org/10.1016/j.fct.2010.10.028. PMid:21056614.

Zhou, L. Z., Johnson, A. P., \& Rando, T. A. (2001). NF kappa B and AP-1 mediate transcriptional responses to oxidative stress in skeletal muscle cells. Free Radical Biology \& Medicine, 31(11), 1405-1416. http://dx.doi. org/10.1016/S0891-5849(01)00719-5. PMid:11728812. 